\title{
Perbandingan Pengembangan Asuransi Syariah di Indonesia dan Malaysia (Analisis Aliran Mazhab Sejarah dan Law as a Tool of Social Engineering)
}

\author{
Inneke Wahyu Agustin \\ Universitas Islam Negeri (UIN) Sunan Kalijaga \\ innekeagustin@gmail.com
}

\begin{abstract}
s
This research discusses the development of Islamic insurance or known as takaful. The focus of discussion on sharia insurance in Indonesia and Malaysia by tracing the history of regulation and the growth of the industry. These two things are compared with the conclusion that you can understand the factors that cause differences in the development of Islamic insurance in Indonesia and Malaysia. With a comparative approach, the conclusion is that Islamic insurance regulations in Indonesia and Malaysia are formed based on the soul of the nation by historical flow of law. Have the same foundation, but Indonesia is slower in responding to regulations. As a result, the growth of the Islamic insurance industry in Indonesia lags behind that of Malaysia. The basic couse is due to the role of law in Indonesia is less responsive because the law acts as a means of social control, for changes in Islamic insurance to be more developed.
\end{abstract}

Keywords: ijtihad; Istiḥsān, Mașlaḥah Mursalah; 'urf; Syar'u Man Qabalanā

\begin{abstract}
Abstrak
Penelitian ini mengkaji tentang salah satu pengembangan asuransi syariah, atau yang dikenal dengan takaful. Pembahasan ini terfokus pada asuransi syariah di Indonesia dan Malaysia dengan menelususri latar belakang sejarah regulasi dan pertumbuhan industrinya. Kedua pembahasan tersebut diperbandingkan dengan kesimpulan dapat memahami faktor penyebab perbedaan pengembangan asuransi syariah di Indonesia dan Malaysia. Dengan pendekatan perbandingan hasil penelitian ini menyimpulkan regulasi asuransi syariah di Indonesia dan Malaysia terbentuk berdasarkan jiwa bangsa yang digagas oleh
\end{abstract}


pemikiran aliran mazhab sejarah. Memiliki pondasi sama namun Indonesia lebih lambat dalam merespon hukum sebagai kebutuhan masyarakat. Akibatnya perkembangan industri asuransi syariah di Indonesia jauh lebih tertinggal daripada Malaysia. Penyebabnya akibat peran hukum di Indonesia kurang responsif karena hukum bertindak sebagai alat kontrol sosial untuk perubahan asuransi syariah agar lebih berkembang.

Kata kunci: Asuransi syariah, Indonesia, Malaysia

\section{Pendahuluan}

Asuransi adalah akad yang mengharuskan perusahaan asuransi (muammin) untuk memberikan kepada nasabah (muammun) sejumlah harta sebagai konsekuensi dari akad tersebut, baik berbentuk imbalan, gaji atau ganti rugi barang dalam bentuk apapun ketika terjadi bencana maupun kecelakaan atau terbuktinya bahaya yang tertera dalam akad. Hal tersebut sebagai imbalan uang (premi) yang dibayarkan secara rutin dan berkala maupun secara kontan dari nasabah kepada perusahaan asuransi di saat hidupnya. Secara singkat erdasarkan definisi tersebut dapat dikatakan asuransi merupakan salah satu cara pembayaran ganti rugi kepada pihak yang mengalami musibah yang dananya diambil dari iuran premi seluruh peserta asuransi (Rivai 2011).

Masalah asuransi dalam pandangan ajaran Islam termasuk ijtihadiyah, artinya hukumnya perlu dikaji sedalam mungkin karena tidak dijelaskan oleh al-Qur'an dan asSunnah secara eksplisit. Para imam mujtahid seperti seperti Abu Hanifah, Imam Malik, Imam Syafi'I, Imam Ahmad bin Hanbal dan para mujtahid yang semasa dengannya tidak memberikan fatwa mengenai asuransi karena pada masanya asuransi belum dikenal. Sistem asuransi baru dikenal di dunia timur pada abad XIX Masehi. Barat telah mengenal sistem asuransi sejak abad XIV Masehi, sedangakn ulama mujtahid besar hidup sekitar II s.d IX Masehi (Suhendi 2013).

Asuransi telah berkembang pesat di beberapa Negara di dunia bahkan asuransi telah berjalan di sebagian besar Negara yang mayoritas Islam. Bisnis asuransi syariah mengalami peningkatan yang cukup signifikan. Perkembangan tersebut cukup memuaskan meskipun terdapat bidang yang masih perlu dikembangkan untuk memenuhi kebutuhan masyarakat. Aktivitas bisnis dimanapun itu tidak boleh lepas dari aturan-aturan yang mengikatnya. Aturan-aturan hukum akan memberikan rambu-rambu yang harus ditaati oleh para pelaku. Apabila bisnis tidak terikat dengan aturan-aturan yang jelas akan menimbulkan distorsi kehidupan yang merugikan masyarakat.

Malaysia merupakan negara yang memiliki eksistensi ekonomi Islam terkemuka diantaranya takaful. Islam merupakan agama yang disahkan oleh negara dan menduduki sebagai mayoritas. Malaysia negara pertama di wilayah Asia Tenggara yang menerbitkan Undang-undang takaful, bahkan sebelum Industri Takaful di resmikan yaitu pada tahun 1984.

al-ạ̣kām Vol. 5, Nomor 1, 2020 
Sedangkan Indonesia yang memiliki jumlah penduduk Islam terbesar, pada tahun 1994 baru mulai mendirikan industri asuransi syariah. Peraturan yang mengikat hanya peraturan yang dikeluarkan oleh Bank Indonesia pada saat itu sebagai pengawas dan regulator keuangan. Undang-undang secara sah diterbitkan tahun 2014.

Perbedaan pembentukan mengenai aturan undang-undang asuransi syariah di Indonesia dan Malaysia sangat menonjol terlebih lagi melihat adanya perbandingan pada minat masyarakat masing-masing negara terhadap asuransi pada perusahaan asuransi syariah. Di Indonesia minat masyarakat terhadap asuransi syariah masih minim dibandingkan asuransi konvensional, hal tersebut dikatakan oleh wakil ketua bidang Keagenan Asosiasi Asuransi Syariah di Indonesia. Anggapan tersebut berdasarkan rendahnya tingkat penetrasi pasar syariah yang disebabkan oleh lambatnya mrket share insutri auransi syariah. Srikandi mengatakan bahwa agen asuransi berlisensi syariah saat ini sekitar 174 ribu orang atau 20 persen dari seluruh total agen asuransi yang ada di Indonesia. Sedangkan, jumlah agen asuransi konvensional sekitar 600 ribu. (Viva 2018). Berdasarkan keadaan ini, pertanyaannya bagaimana sejarah pembentukan hukum asuransi syariah di kedua negara ini apabila dikupas dengan teori aliran mazhab sejarah? Bagaimana perbandingan perkembangan industri dari kedua negara ini? Kemudian, faktor apa yang menyebabkan perbedaan tersebut?

Pembahasan kajian ini adalah pustaka dengan menggunakan pendekatan perbandingan. Sumber-sumber yang digunakan meliputi Undang-undang dan sumber yang dapat dipertanggungjwabkan. Pengumpulan data dari sumber primer, yaitu peraturanperaturan tentang asuransi syariah yang diterbitkan oleh Indonesia dan Malaysia, serta data-data statistik asuransi syariah dari sumber web resmi pemerintah. sumber sekunder yaitu, karya ilmiah yang lebih dahulu terbit dan literature-literatur yang memiliki keterkaitan dengan obyek pembahasan.

\section{Sejarah Pembentukan Undang-undang Asuransi Syariah}

Berbicara mengenai sejarah pasti akan terbagi menjadi beberapa fase saat zamannya tengah berlangsung. Untuk mengetahui perjalanan yang melatar belakangi pembentukan undang-undang asuransi syariah di negara Indonesia dan Malaysia berhubungan dengan fase pra-penjajahan, masa penjajahan, setelah kemerdekaan dan masa kontemporer atau masa kini.

\section{Indonesia}

J.L.A. Brandes dan N.J. Krom mencoba untuk mengungkap kesejatian peradaban dan kebudayaan Indonesia apakah mecakup aspek ekonomi. Menurutnya sentuhan kebudayaan Indonesia sebelum kebudayaan India adalah kebudayaan tradisi (J. Burhanudin 1998). Kegiatan perekonomian saat itu bersifat bedarfsdeckung yaitu menggambarkan pragmatisme 
kehidupan ekonomi masyarakat (Ali 1995). Bagi masyarakat hidup dimanfaatkan untuk memenuhi keperluan terbatas. Usaha mengumpulkan barang yang bernilai aspek ekonomis dilakukan tanpa disertai tujuan yang rasional dan efisien. Gotong royong merupakan organisasi ekonomi kebudayaan Indonesia asli yang sebatas konsep moral ekonomi, bukan konsep ekonomi (Yasin 2009).

Melihat kegiatan ekonomi yang ada di Indonesia sebelum adanya para penjajah tidak ada kegiatan yang menyatakan atau menyerupai sistem asuransi. Masyarakat berdagang dengan rasa kepercayaan yang tinggi, pemikiran tentang keuangan yang dihadapi tidak sejauh dengan apa yang terjadi. Meskipun risiko pada masa ini sudah ada karena pastilah setiap kehidupan mengandung risiko. Asas utama masyarakat Indonesia dari masa itu mengutamakan asas gotong royong. Praktik secara lapangan terlihat hampir mirip karena ditanggung secara bersama. Namun, prospek untuk menjadikan suatu ladang bisnis belum nampak.

Sampai pada masa penjajahan asuransi mulai dikenal, kegiatan asuransi sudah menyebar saat perekonomian zaman Belanda yang saat ini di wariskan dan dikenal dengan asuransi konvensional.Alasan asuransi konvensional jauh lebih dahulu merebak ke masyarakat karena pengaruh Belanda. Belanda mendirikan perusahaan asuransi kerugian pertama di Indonesia yaitu Bataviasche Zee End Brand Asrantie Maatschappij pada tahun 1853 dengan perlindungan utama terhadap resiko kebakaran dan asuransi pengangkutan. Keberadaan hukum asuransi di Indonesia berakar dari Kodifikasi Hukum Perdata (Code civil) dan Hukum Dagang (code de commerce) pada permulaan abad kesembilanbelas semasa pemerintahan kaisar Napoleon di Perancis. Saat itu, Hukum Dagang Belanda hanya memuat pasal-pasal mengenai asuransi laut sampai diundangkannya rancangan Kitab Undangundang Hukum Dagang (Wet Boek van Koophandel) tahun 1838 yang memuat peraturanperaturan mengenai asuransi kebakaran, asuransi hasil bumi dan asuransi jiwa. Asuransi baik bentuk dan pengertiannya berasal dari Belanda sebagai pengimpor asuransi sebagai bentuk hukum (rechtsfiguur) di Indonesia. Caranya dengan mengundangkan Burgelijk Wetboek dan Wetboek van Koophandel, yang diumumkan pada 30 April 1847, dan termuat dalam staatsblad 1847 Nomor 23 (Prodjodikoro 1986).

Setelah bangsa Indonesia merdeka, maka tahun 1950 asuransi mulai tumbuh kembali yang mana pada periode ini bangsa Indonesia mulai membangun perekonomiannya sendiri. Perusahaan-perusahaan asuransi yang tadinya dibekukan mulai dibuka kembali (Rusman 2016). Merebaknya ekonomi sistem warisan Belanda membuat umat Islam yang tekun pada kegiatan ekonomi mulai resah, karena kegiatan perekonomiannya terdapat unsur riba. Pergerakan ekonomi Islam selanjutnya terbawa sepanjang masa orde baru hampir 24 tahun (1967-1991). Pembahasan persolan masih abstrak karena tanpa didukung realitas lapangan sehingga mengakibatkan kejenuhan. Tanggung jawab dalam mengembangkan teori untuk

al-ạ̣kām Vol. 5, Nomor 1, 2020 
melakukan penelitian empiris masih kurang dirasakan. Kelompok pemikir cenderung menunggu, mengharap, dan menilai (Rahardjo 1999).

Sampai halnya tibalah tonggak sejarah perekonomian Islam di Indonesia, ladang pembuka segala aspek literasi keuangan pada saat itu adalah perbankan syariah yaitu, PT. Bank Muamalat Indonesia. Bank Muamalat Indonesia (BMI) didirikan secara resmi oleh pemerintah pada tahun 1922 (Bank Muamalat 2016). Berdirinya Bank Muamalat Indonesia sebagai lembaga keuangan syariah pertama kali di Indonesia sangat mencuri perhatian, terlebih produk-produk yang ditawarkan. Lembaga Perbankan Syariah ini akhirnya menjadi tonggak jayanya ekonomi syariah di Indonesia. Lembaga keuangan laiinya begitu signifikan terus menerus meningkat baik secara kuantitas maupun kualitatif, termasuk asuransi syariah/ asuransi takaful (Yasin 2009).

Kesepakatan antara ICMI, BMI, dan Perusahaan Asuransi Tugu Mandiri, Departemen Keuangan Republik Indonesia, dan para pengusaha muslim Indonesia tanggal 27 Juli 1993 untuk menyusun Tim Pembentukan Asuransi Takaful Indonesia (TEPATI). Tindak lanjut TEPATI melahirkan Takaful Indonesia sebagai holding company PT Asuransi Takaful Keluarga dan PT Asuransi Takaful Umum Asuransi Jiwa dan Umum Syariah dengan bantuan teknis dari Syarikat Takaful Malaysia Bhd (STMB) (Nurwidiatmo 2008).

Awal berdirinya perusahaan asuransi syariah di saat kondisi hukum di Indonesia tidak mempunyai aturan khusus yang menaungi kegiatan perasuransian dengan prinsip syariah. Saat itu Undang-undang perasuransian yang berlaku di Indonesia adalah Undang-undang No. 2 Tahun 1992 tentang usaha perasuransian dan peraturan-peraturan turunannya. Tidak adanya payung hukum secara khusus tidak menghalangi lembaga perasuransian syariah terus berjalan, dengan beban tidak tunduk secara penuh pada peraturan berlaku (NU Online 2018).

Tahun demi tahun berlalu hingga sampai tujuh tahun kemudian barulah keluar Fatwa Dewan Syariah Nasional Majelis Ulama Indonesia (DSN-MUI) No. 21/DSN$\mathrm{MUI} / \mathrm{X} / 2001$ tentang Pedoman Umum Asuransi Syariah. Fatwa ini dapat dijadikan pedoman tetapi tidak berkekuatan hukum dalam hukum Nasional.Agar ketentuan Asuransi Syariah memiliki kekuatan hukum, maka perlu dibentuk peraturan yang termasuk peraturan perundangundangan yang ada di Indonesia meskipun dirasa belum memberi kepastian hukum yang lebih kuat, peraturan tersebut yaitu Keputusan Menteri Keuangan RI No. 426/ KMK.06/2003, Keputusan Menteri Keuangan RI No. 424/KMK.06/2003, Keputusan Menteri Kuangan RI No. 422/KMK.06/2003dan Keputusan Direktorat Jendral Lembaga Keuangan No. 4499/LK/2000, Peraturan Pemerintah No. 39 tahun 2008, Keputusan Menteri Keuangan No. 11/PMK.010/2011.

Terdapat dua alasan yang dianggap menghambat munculnya UU Asuransi Syariah. Pertama, UU tersebut dianggap tidak sesuai dengan prinsip dasar Indonesia berdasarkan 
Pancasila. Historis norma-norma yang bersumber dari hukum Islam di bidang ekonomi telah lama memudar dari perangkat hukum akibat politik hukum penjajah yang sistematis mengikis keberlakuan hukum Islam. Akibatnya asuransi dan lembaga keuangan lainnya terbiasa menerapkan ketentuan hukum buatan Belanda. Kedua, kurangnya political will pemerintah untuk memprivatisasi usaha perasuransian secara umum. Terbukti kurangnya prioritas terhadap pengesahan RUU Perasuransian.

Perdebatan mengani RUU Perasuransian yang tidak terlihat kesungguhannya untuk segera disahkan menjadi UU terus terjadi. Pada Prolegnas (Program Badan Legislasi Nasional) tahun 2010/2014 posisi RUU Perasuransian menduduki urutan ke-84 (Dewan Perwakilan Rakyat Republik Indonesia 2010). Hal tersebut menjadikan pesimis bahwa RUU Perasuransian akan disahkan menjadi UU. Karena pemberian nomor RUU menentukan mana yang harus diprioritaskan dan mana yang harus menunggu antrian.

Perkembangan aturan hukum asuransi syariah menunjukkan perhatian dari pemerintah mulai tahun 2010 yang ditandai dengan masuknya RUU Perasuransian atas perubahan UU No.2 tahun 1922 tentang Usaha Perasuransian yang masuk dalam draft prolegnas 2010-2014. Keinginan pemerintah merevisi UU Perasuransian telah lama sejak Tahun 2011 dan ditargetkan akhir tahun 2012 selesai. Namun RUU baru masuk pembahasan ke DPR tahun 2012. Alasan dasar keterlambatan ini terjadi karena menunggu berdirinya lembaga Otoritas Jasa Keuangan sebagai wasit industri keuangan (Kontan 2018).

Setelah terbentuknya OJK, tahun 2013 Pemerintah dan Komisi XI DPR RI membentuk panitia kerja untuk membahas RUU tentang usaha perasuransian.Tepat pada hari Selasa, 23 September 2014 yang lalu, rapat paripurna DPR RI menyetujui RUU Usaha Perasuransian menjadi Undang-undang sebagai pengganti Undang-undang No. 2 tahun 1992 tentang Usaha Perasuransian. Perdebatan yang dinamis mewarnai pembahasan RUU antara Pemerintah dan DPR mengenai bebrapa topic tertentu yang krusial. Perubahan dalam pembahasan berupa sistematika penulisan RUU, penambahan jumlah pasal (dari sebelumnya 72 Pasal menjadi 92 Pasal) dan penambahan bab (yang semula 15 bab menjadi 18 bab (Umam 2014). Lahirlah Undang-undang No. 40 Tahun 2014 tentang Perasuransian.

\section{Malaysia}

Masa sebelum datangnya kendali Inggris di Malaysia, ekonomi dikendalikan oleh penguasa melayu. Sedangkan hukum berdagang yang berlaku di Malaysia sebelum datangnya penjajah adalah hukum Islam bercampur dengan hukum adat (Rahim and Ramli 2007). Jejak sejarah perekonomian berunsur Islam pertama kali di Batu bersurat Terengganu. Kedua, pada Undang-undang Malaka yang berlaku pada zaman kerajaan Malaka yang didirikan Parameswara tahun $1402 \mathrm{M}$. Istilah asuransi pada zaman itu memang belum ada namun, ketika menelusuri sejarah sistem atau konsep yang mririp dengan asurnasi sudah tampak.

al-ạ̣kān Vol. 5, Nomor 1, 2020 
Hal tersebut karena manusia sadar resiko disetiap hal yang dijalankan. Terutama pada aktivitas perdagangan, risiko barang dagangan sangat diperhatikan. Terlihat ketika Undangundang Laut malaka yang isinya menganai peraturan akan beberapa hal yang timbul pada kapal. Kapal merupakan kendaraan perdagangan masyarakat kala itu agar dapat berjalan. Perdagangan dilakukan antara pulau satu ke pulau yang lainnya, tidak heran apabila banyak berbagai etnis China, Arab, India yang mendominasi di Selat Malaka. Sehingga, konsep yang menyerupai asuransi telah ada di Zaman Kesultanan Melaka (Hadijah 2018).

Undang-undang yang berlaku di samping Kanun Malaka terdapat beberapa teks Undang-undang Melayu lama yang dipakai di beberapa negeri Melayu, seperti UU Pahang, UU Negeri Sembilan, UU Kedah dan UU Johor. UU Pahang juga dipakai di Negeri Perak dan Johor. Sayangnya tidak ditemukan penjelasan tentang keberadaan UU Kedah dan Johor. Teks Undang-undang Melayu tersebut dipengaruhi oleh Undang-undang Melaka. Bagian-bagian yang dipengaruhi Islam adalah bab-bab perkawinan, jual beli (muamalat), dan pengadilan (Nasution 2002, 2009).

Konsep asuransi tidak dapat dilacak dalam Undang-undang yang telah dijelaskan sebelumnya. Namun, terdapat kebiasaan adat Melayu ketika anggota dari sebuah komunitas memberikan sumbangan sukarela atau sumbangan lain kepada keluarga yang ditinggalkan dari orang yang sudah meninggal. Hal itu dilakukan untuk mengurangi penderitaan mereka dan membantu dengan pemakaman dan penegluaran laiinya. Fakta tersebut tampaknya pada tingkat yang sangat mendasar menyerupai konsep asuransi. Namun ini merupakan praktik masyarakat, bukan prinsio hukum adat yang ketat dan oleh karena itu tidak disebutkan dalam salah satu Hukum Melayu. Namun ketentuan dalam Hukum Laut Malaka menyatakan adanya beberapa jenis kerugian yang dilakukan saat berlayar. Ketika terjadinya angin kencang dan kapal tersebut menabarak batu, hal itu tidak dianggap sebagai kecelakaan tetapi kesalahan karena dalam kondisi badai kapal tidak diperbolehkan melaut. Kerugian yang didapat dari kesalahan itu di tanggung menjadi tiga bagian. Satu ditanggung oleh pemilik kapal yang rusak itu, dua lainnya di tanggung oleh orang-orang yang bertanggug jawab atas kehilangan tersebut (Mahmood 1988).

Awal abad ke-16 Malaka mulai goyah dan menunjukkan keterpurukannya akibat permasalahan internal serta serangan para pedagang Eropa yang memiliki niat untuk menguasai Malaka. Dari beberapa bangsa seperti Belanda dan Portugis, Inggris berhasil menduduki wilayah tersebut dengan perlahan-lahan mengenalkan corak kehidupannya. Inggris membawa sitem perekonomiannya dan mengadaptasikan diri dengan perekonomian adat Melayu (Nasution 2002). Meskipun praktik adat di masyarakat melayu telah mengenal dan adanya konsep asuransi. Inggris meneganalkan praktik asuransi dengan secara keutuhan dan tersistematis. Asuransi dikenal pada abad ke 18 dan diperkenalkan secara resmi abad ke-19 melalui rumah-rumah agen yang bertindak sebagai agen untuk menyediakan fasilitas 
penjaminan atas nama perusahaan asuransi yang berbasis di London (Mahmood 1988; Billah 2010).

Setelah merdeka pada tahun 1957, kebijakan nasionalis memberi banyak dorongan kepada perusahaan domestik untuk meningkatkan pangsa pasar mereka.Pemerintah melangkah untuk memperbaiki situasi dengan memperkenalkan Undang-Undang Asuransi 1963. Perawalan tahun pasca kemerdekaan Malaysia sistem perekonomian secara publik masih terdominasi oleh perekonomian kultur penjajah. Babak baru perjalanan pembentukan sistem keuangan Islam yang komprehensif di Malaysia dimulai pada tahun 1969 dengan penciptaan Lembaga Urusan dan Tabung Haji (LUTH) (Noordin and Fares 2016). Secara Politik perekonomian Islam Malaysia dimulai ketika kebijakan New Economic Policy (NEP) atau Dasar ekonomi Baru (DEB) diperkenalkan pemerintah Malaysia tahun 1970 (Milne and Diane, n.d.). Tahun 1970-an Keuangan Islam telah berkembang pesat. Hal ini mendorong para munculnya lembaga-lembaga keuangan Islam, seperti Islamic Banking atas desakan dan karena kebutuhan masyarakat Melayu Muslim. Selain Lembaga Perbankan, lembaga yang menjalankan konsep asuransi juga mendapatkan perhatian. Pada bulan Juni 1972, National Fatwa Committee menyatakan konsep asuransi konvensional (khususnya asuransi jiwa) yang diatur oleh Undang-undang Asuransi Malasysia (Malaysia Insurance Act 1963) bertentangan dengan aturan syariah (Thanasegaran 2018).

Tahun 1981 dibentuk Satuan Tugas untuk mempelajari Pembentukan Usaha Asuransi syariah di Malaysia sebagai tujuan membentuk asuransi syariah sebagai pelengkap perbankan syariah (Haron 2005).

Komite Fatwa menghendaki adanya pembentukan asuransi namun mempunyai skema sesuai dengan prinsip-prinsip Islam yang mampu sebagai alternatif bagi masyarakat (Billah 2010). Pada tahun 1982 pemerintah membentuk Satuan Tugas untuk mempelajari kemungkinan-kemungkinan alternatif yang terkait dengan implementasi asuransi Islam. Satuan Tugas tersebut memberikan arahan dan rekomendasi kepada Parlemen Malaysia untuk membuat dan memberlakukan Undang-undang Takaful 1984, sehingga dapat melahirkan Sistem Takaful di Malaysia (Thanasegaran 2018). Laporan yang disampaikan oleh Satuan Tugas di setujui pada tahun 1984 dan melahirkan Takaful Act 1984.

Dalam perjalanan waktu seiring dengan keadaan dan waktu yang terus berkembang Lembaga keuangan Islam di Malaysia terus merekah dan mendapat perhatian dalam ranah global. Industri takaful di Malaysia telah mencapai sekitar 30 tahun. Berbagai perubahan telah dilakukan oleh regulator Bank Negara Malaysia (BNM) untuk memastikan penguatan dan stabilitas industri takaful.

Merespon perkembangan keuangan Islam di Malaysia, pemerintah membuat aturan yang mencangkup semua lembaga-lembaga keuangan Islam. Pada 22 Maret 2013 Undangundang Layanan Keuangan Islam (UU 759) atau Islamic Financial Services Act (Act 759)

al-ạ̣kām Vol. 5, Nomor 1, 2020 
diterbitkan dalam Lembaran Negara dan mulai berlaku tanggal 1 Juli 2013. Terbentuknya Undang-undang ini untuk memprmosikan stabilitas keuangan dan kepatuhan terhadap prinsip-prinsip syariah mulai dari perizinan, pengoperasiannya, hingga tutupnya lembaga keuangan Islam. Terlebih Malaysia menjadi pemimpin dan unggul dalam bidang keuangan Islam dan sebagai ujung tombak menuju pusat keuangan Islam dunia (Thajudeen 2014).

\section{Perkembangan Industri Asuransi Syariah}

\section{Indonesia}

Perusahaan pertama kali didirikan tahun 1994 yaitu PT Asuransi Takaful Indonesia. Munculnya perusahaan asuransi syariah mengalami pro dan kontra di masyarakat Indonesia. Hukum asuransi syariah merupakan pergumulan antara pemahaman hukum syariat dengan relaitas yang terjadi. Sehingga pada tahun 2001 Majelis Ulama Indonesia mengeluarkan Fatwa mengenai Pedoman Umum Asuransi syariah, Fatwa No. 21/DSN-MUI/X/2001. Fatwa ini dikeluarkan untuk mengembangkan produk hukum asuransi syariah (takaful), keberadaan fatwa DSN-MUI mempunyai fungsi yang fundamental (B. Burhanudin 2010).

Berdirinya Asuransi Syari'ah di Indonesia tidak diikuti dengan regulasi yang memumpuni. Keberadaan asuransi syariah di Indonesia secara konstitusi masih lemah dan masih perlu kebijakan politik yang mendukung pemerintah Indonesia saat itu. Selama 20 tahun keluarlah peraturan yang mengatur asuransi syari'ah yaitu Undang-undang No. 40 Tahun 2014 tentang Perasuransian. Terbitnya Undang-undang No. 40 Tahun 2014 tentang Perasuransian tampak jelas tercantum dalam penjelasan Undang-undang tersebut pada Ketentuan umum. Upaya meenciptakan industry perasuransian yang lebih sehat, dapat diandalkan, amanah, dan kompetitif secara umum dilakukan, baik dalam penetapan ketentuan baru maupun penyempurnaan ketentuan yang telah ada. Perwujudan upaya tersebut salah satunya dalam bentuk penetapan landasan hukum bagi penyelenggaraan usaha asuransi syariah dan usaha reasuransi syariah. Hal ini merupakan kabar yang menggembirakan bagi umat Muslim di Indonesia bagi yang berkontribusi di keuangan asuransi tanpa menanggung beban mengenai landasan hukum positifnya.

Perkembangan asuransi syariah belakangan ini dinilai cukup membahagiakan. Banyaknya berdiri perusahaan asuransi syariah baik unit usaha atau tidak telah membuka pandangan masyarakat terhadap fasilitas yang semakin mudah. Bahkan perusahaan asing membidik Indonesia sebagai pasar terbesar karena memiliki jumlah umat Muslim yang besar. Berikut adalah pertumbuhan asuransi syariah di Indonesia yang bersumber dari laman OJK: 
Tabel 1 Pertumbuhan Perusahaan Asuransi Syariah Indonesia 2013-2018

\begin{tabular}{|c|c|c|c|c|c|c|c|}
\hline \multicolumn{2}{|l|}{ Keterangan } & 2013 & 2014 & 2015 & 2016 & 2017 & 2018 \\
\hline \multirow{3}{*}{$\begin{array}{l}\text { Perusahaan } \\
\text { Asuransi Syariah }\end{array}$} & Asuransi Jiwa Syariah & 3 & 3 & 5 & 6 & 7 & 7 \\
\hline & Asuransi Umum Syariah & 2 & 2 & 3 & 4 & 5 & 5 \\
\hline & Reasuransi Syariah & - & - & - & 1 & 1 & 1 \\
\hline \multicolumn{2}{|l|}{ Total } & 5 & 5 & 8 & 11 & 13 & 13 \\
\hline \multirow{3}{*}{$\begin{array}{l}\text { Unit Usaha } \\
\text { Asuransi Syariah }\end{array}$} & Asuransi Jiwa Syariah & 17 & 18 & 19 & 21 & 23 & 23 \\
\hline & Asuransi Umum Syariah & 24 & 23 & 23 & 24 & 25 & 24 \\
\hline & Reasuransi Syariah & 3 & 3 & 3 & 2 & 2 & 2 \\
\hline \multicolumn{2}{|l|}{ Total } & 49 & 45 & 44 & 47 & 50 & 49 \\
\hline
\end{tabular}

Tabel 2 Pertumbuhan Aset Asuransi Syariah Indonesia 2013-2018

\begin{tabular}{|l|l|c|c|c|c|c|c|}
\hline \multicolumn{2}{|l|}{ Keterangan } & $\mathbf{2 0 1 3}$ & $\mathbf{2 0 1 4}$ & $\mathbf{2 0 1 5}$ & $\mathbf{2 0 1 6}$ & $\mathbf{2 0 1 7}$ & $\mathbf{2 0 1 8}$ \\
\hline \multirow{3}{*}{$\begin{array}{l}\text { Asset } \\
\text { (miliar Rp) }\end{array}$} & Asuransi Jiwa Syariah & 12,792 & 18,051 & 21,614 & 27,079 & 33,484 & 34,474 \\
\cline { 2 - 8 } & Asuransi Umum Syariah & \multirow{2}{*}{3,869} & 3,310 & 3,786 & 4,797 & 5,370 & 5,621 \\
\cline { 2 - 6 } & Reasuransi Syariah & & 1,003 & 1,119 & 1,368 & 1,666 & 1,864 \\
\hline \multicolumn{2}{|l|}{ Total Aset (miliar Rp) } & $\mathbf{1 6 , 6 6 1}$ & $\mathbf{2 2 , 3 6 4}$ & $\mathbf{2 6 , 5 1 9}$ & $\mathbf{3 3 , 2 4 4}$ & $\mathbf{4 0 , 5 2 0}$ & $\mathbf{4 1 , 9 5 9}$ \\
\hline
\end{tabular}

\section{Malaysia}

Tahun 1972 Komite Fatwa Nasional Dewan Urusan Islam Malaysia menyatakan bahwa asuransi konvensional tidak sesuai dengan syariah. Fiqh Academy of the Organization of Islamic Conferences mendeklarasikan hal serupa. Sehingga masyarakat perlu adanya mencari alternatif lain membangun konsep asuransi berdasarkan nilai-nilai Islami (Fauzi and Naadia 2016). Akhirnya konsep asuransi sesuai syariah atau takaful pertama kali diperkenalkan di Malaysia pada tahun 1985 ketika operator takaful pertama didirikan untuk memenuhi kebutuhan masyarakat umum agar dilindungi berdasarkan prinsip-prinsip Islam. Dasar hukum untuk pembentukan operator takaful adalah Takaful Act yang mulai berlaku pada tahun 1984. Operasi takaful diatur dan diawasi oleh BNM sejak tahun 1988 dengan penunjukan Gubernur BNM sebagai Direktur Jenderal Takaful (International Business Public 2015).

Mudahnya perkembangan Islam di Malaysia berdampak pada kegiatan regulasi dan pemahaman masyarakatnya terhadap kegiatan bercorak Islam termasuk kegiatan perekonomian.Dampak yang terjadi pada sektor keuangan Islam Malaysia mampu mencapai pertumbuhan yang signifikan dan telah menjadi pertimbangan dalam kacamata global. Malaysia menempati Ranking Pertama dalam sektor Islamic Finance dari lima belas 
negara pada The State of the Global Islamic Economy Report 2018/19 (Dubai the Capital of Islamic Economy 2016). Malaysia telah merencanakan untuk terus membuat peraturan baru sebagai laju untuk membuat sistem keuangan Islam mudah dipahami dan berjalan sesuai koridornya. BNM merencanakan meluncurkan peraturan-peraturan baru pada bidang takaful oleh Takaful Operational Framework yang dapat membawa kejelasan lebih besar menggunakaan standar syariah dalam struktur model takaful (Dubai the Capital of Islamic Economy 2016).

Perkembangan Takaful di Malaysia dinilai terkemuka dalam perekonomian Islam kontemporer secara global. Malaysia mempunyai dua kategori utama dalam produk takaful yang ditawarkan, Takaful Umum dan Takaful Keluarga. Mulai Tahun 2013 dan diharapkan sampai pertengahan 2018 perusahaan harus melakukan Merger dan Akuisisi karena IFSA 2013 mensyaratkan perusahaan takaful yang memegang lisensi gabungan untuk memisahkan bisnis mereka menjadi takaful umum dan takaful keluarga (Yeong 2018). Perkembangan yang terjadi dari tahun 2013-2018 pada tabel berikut.

Tabel 3 Pertumbuhan Operator Takaful Malaysia 2013-2018

\begin{tabular}{|l|l|c|c|c|c|c|c|}
\hline \multicolumn{2}{|l|}{ Keterangan } & 2013 & $\mathbf{2 0 1 4}$ & $\mathbf{2 0 1 5}$ & $\mathbf{2 0 1 6}$ & $\mathbf{2 0 1 7}$ & $\mathbf{2 0 1 8}$ \\
\hline \multirow{2}{*}{$\begin{array}{l}\text { Jumlah } \\
\begin{array}{l}\text { Perusahaan } \\
\text { Takaful }\end{array}\end{array}$} & Takaful Keluarga & 12 & 11 & 11 & 11 & 11 & 11 \\
\cline { 2 - 8 } & Takaful Umum & 4 & 4 & 4 & 4 & 4 & 4 \\
\cline { 2 - 8 }
\end{tabular}

Tabel 4 Pertumbuhan Aset Takaful Malaysia 2013-2018

\begin{tabular}{|l|l|c|c|c|c|c|c|}
\hline \multicolumn{2}{|l|}{ Keterangan } & $\mathbf{2 0 1 3}$ & $\mathbf{2 0 1 4}$ & $\mathbf{2 0 1 5}$ & $\mathbf{2 0 1 6}$ & $\mathbf{2 0 1 7}$ & $\mathbf{2 0 1 8}$ \\
\hline \multirow{2}{*}{$\begin{array}{l}\text { Jumlah } \\
\text { Asset }\end{array}$} & $\begin{array}{l}\text { Takaful } \\
\text { Keluarga }\end{array}$ & $17,952.2$ & $19,619.2$ & $21,389.1$ & $23,189.1$ & $25,638.7$ & $27,616.9$ \\
\cline { 2 - 7 } & $\begin{array}{l}\text { Takaful } \\
\text { Umum }\end{array}$ & $2,982.0$ & $3,127.0$ & $3,321.9$ & $3,592.5$ & $3,644.6$ & $3,756.9$ \\
\hline $\begin{array}{l}\text { Total Jumlah Asset (RM } \\
\text { Million) }\end{array}$ & $\mathbf{2 0 , 9 3 4 . 2}$ & $\mathbf{2 2 , 7 4 6 . 3}$ & $\mathbf{2 4 , 7 1 1 . 0}$ & $\mathbf{2 6 , 7 8 1 . 6}$ & $\mathbf{2 9 , 2 8 3 . 3}$ & $\mathbf{3 1 , 3 7 3 . 8}$ \\
\hline
\end{tabular}

Takaful Malaysia telah mengalami pertumbuhan dan transformasi yang pesat semenjak 35 tahun yang lalu. Saat ini merujuk pada peraturan IFSA 2013 Operator Takaful telah melakukan merger menjadi dipisahkan Family Takaful dan General Takaful. Sehingga sampai pada catatan laporan tahunan 2018 terdapat 11 Perusahaan Takaful Keluarga dan 4 Perusahaan Takaful Umum serta 4 Perusahaan Retakaful. 


\section{Analisis Perbandingan Sejarah terbentuknya Undang-undang Asuransi Syari'ah}

Sejarah memilik peran fundamental dalam pengembangan hukum di masa depan. Indonesia dan Malaysia secara domino menjadi pusar perekonomian Islam di kawasan Asia Tenggara. Memiliki banyak kesamaan dari mulai suku, bermacam etnis dan ras, negeri yang memiliki kecenderungan Islam sebagai agama yang dianut mayoritas masyarakatnya. Berdasarkan sejarah masuknya Islam di Malaysia maupun Indonesia sama-sama melalui pintu perdagangan suku Arab. Islam mulai diterima dan menyebar membaur bersama kebiasaan-kebiasaan adat masyarakatnya. Perkembangan segala aspek sosial, ekonomi, politik, dan hukum Islam berjalan dengan mulus dan menjadikan Islam sebagai karakter dan bangsa Indonesia dan Malaysia.

Berdasarkan literatur sejarah di Indonesia Maupun Malaysia, Islam menyebar kesegala aspek yang dimulai dengan jalan perekonomian perdagangan. Kegiatan ekonomi Islam terakumulasi menjadi kebiasaan-kebiasaan di masyarkat. Pada masa sebelum penjajahan secara mengikat tidak ada kegiatan perekonomian berdasarkan prinsip Islam meskipun Kerajaan-kerajaan Islam telah menyebar. Literatur tidak menyebutkan secara detail mengenai kesejarahan Islam di Indonesia dengan lata belakang ekonomi. Sedangkan di Malaysia, kedatangan Islam menyatu dengan kalangan elit Kerajaan sehingga kebijakan raja yang dikeluarkan telah mengandung unsur-unsur ajaran Islam, meskipun secara perlahan. Pada beberapa temuan aturan-aturan yang di buat Kerajaan tercantum adanya peraturan tentang Muamalah. Beberapa undang-undang islam yang terdapat pada beberapa wilayah di Malaysia telah mengindikasikan adanya aturan Islam. Namun kebanyakan aturan-aturan tersebut lebih menekankan pada aspek peribadatan dan kekeluargaan.

Baik dari Indonesia maupun Malaysia pada masa awal kesejarahan Islam tidak terdapat kegiatan perekonomian dengan adanya lembaga keuangan. Apalagi praktek asuransi syariah yang merupakan turunan dari adanya Perbankan Syariah. Tetapi secara kegiatan yang meyerupai sistem asuransi di Indonesia dan Malaysia telah ada meskipun berbentuk berbeda. Dasar kegiatan asuransi yang gotong royong untuk memikul beban dari kerugian atau musibah yang dihadapi orang lain menjadi praktik kebiasaan yang ada di masyarakat. Karakter masyarakat Indonesia dan Malaysia yang tidak jauh berbeda menjadikan pondasi dasar adanya kebiasaan kultur gotong royong pada kedua wilayah tersebut. Sedikit berbeda, karena selat Malaka merupaka jalur perdagangan laut, pemerintahan Malaka membuat undang-undang laut yang mengatur segala sesuatu tentang kapal. Semua hal itu, terjadi karena kesadaran resiko yang terjadi dari kecelakaan akibat badai di laut. Tampaknya berdasarkan sejarah praktek asuransi lebih dominan berkembang lebih dahulu di masyarakat Malaysia.

Keadaan berubah setelah adanya penjajah yang mendiami dan merebut kekuasaan di kedua wilayah Indonesia dan Malaysia. Malaysia sejak awal telah dijajah oleh bangsa

\footnotetext{
al-ạ̣kām Vol. 5, Nomor 1, 2020
} 
Portugis, namun keadaan tersebut tidak lama. Kemudian Inggris dan Belanda berebut kekuasaan, dengan Perjanjian yang dibuat oleh kedua kolonial tersebut menjadikan wilayah bagian utara yang saat ini dikenal Malaysia dikuasai Inggris dan wilayah bagian selatan yang saat ini Indonesia dikuasai Belanda. Masing-masing bangsa kolonial tersebut memiliki ciri, karakteristik, budaya dan ajaran yang berbeda. Inggris dengan common law system dan Belanda dengan civil law system.

Keduanya kolonial yang menjajah di tempat yang berbeda tersebut, sama-sama mengenalkan kehidupan-kehidupan yang jauh lebih modern. Inggris dan Belanda samasama datang dengan berdagang dan mulai tergiur dengan kekayaan alam yang dapat dimanfaatkan untuk memperkaya kehidupan. Atas kepentingan perdagangan keduanya mulai mendirikan industri asuransi dan memperkenalkan bentuk dan definisi dari asuransi tersebut. Perusahaan-perusahaan asurnasi mulai berdiri dan terus berkembang, baik di Indonesia maupun Malaysia. Sampai pada kedua negara tersebut mengalami kemerdekaan perusahaan-perusahaan yang didirikan oleh kolonial masik eksis, hanya saja mulai dinasionalisasikan dengan bentuk perubahan nama namun masih pada pola yang sama.

Keadaan gelisah semenjak ekonomi Islam mulai muncul, hal ini di dasarkan pada masing-masing negara memiliki dasar Islam yang kuat. Malaysia secara konstitusional mengakui agama Islam sebagai agama yang sah. Sedangakan, Indonesia yang memiliki masyarakat mayoritas pemeluk agama Islam. Masyarakat Islam memiliki kebiasaan, tradisi, sikap, dan perasaan persatuan. Sebenarnya Islam bukan merupakan karakteristik masyarakat Indonesia dan Malaysia. Penerimaan Islam pada masyarakat adat Indonesia dan Malaysia menjadikan besarnya gelembung arus Islam, sehingga menjadikan keduanya sebagai negara muslim. Perkembangan tersebut menjadikan Indonesia dan Malaysia yang memiliki karakteristik Islam tersendiri.Karakteristik ini membentuk menjadi sebuah jiwa bangsa. Artinya Islam melekat dan Negara seharusnya turut andil untuk mendengarkan aspirasi yang diampaikan oleh masyarakat.

Secara historis asas-asas Islam dalam bidang perniagaan mulai mencuat tahun 1950, yang terjadi di Pakistan. Malaysia sebagai penggerak ekonomi Islam pertama kali setelah Negara-negara Islam di kawasan Timur lainnya. Mufti Malaysia mengeluarkan fatwa bahwa asuransi yang selama ini yang berjalan di Malaysia bertentangan dengan prinsip-prinsip ajaran Islam. Kemudian tahun 1984 mendirikan Indutri Takaful sebagai alternatif bagi masyarakat muslim Malaysia untuk memenuhi kebutuhan masyarakat muslim.

Selang beberapa tahun, yaitu tahun 1994 kemudian Indonesia mengikuti pendirian asuransi syariah yang berkiblat pada negara Malaysia. Bahkan tim secara khusus dari Indonesia bertolak ke Malaysia untuk mempelajari pendirian industri asuransi syariah. Modal pendirian industri asuransi syariah di Indonesia juga mendapat asupan dana dari Malaysia. Pendirian asuransi syariah di Indonesia diprakarsai oleh kelompok muslim yang 
gelisah karena asuransi konvensional yang mengandung unsur riba, gharar, dan maysir. Asuransi Syariah di Indonesia dan Malaysia mengalami perbedaan waktu yang cukup jauh dalam pembentukan awalnya. Indonesia lebih terlambat dalam mendirikan indutri keuangan asuransi sayriah di bandingkan Malaysia.

Bukan sekedar Industri yang mengalami keterlambatan, aturan mengenai pedoman berjalannya Industri asuransi syariah Indonesia dapat dikatakan sangat jauh mengalami keterlambatan. Pada saat pendirian Industri Takaful tahun 1984, Malaysia lebih dahulu menyiapkan peraturan perundang-undangan baru mendirikan perusahaan yang diresmikan tahun 1985. Sedangkan Indonesia lebih dahulu mendirikan perusahaan tanpa ada kepastian hukum untuk menjamin perusahaan asuransi syariah tersebut. Hanya dengan ketetapan fatwa MUI Indonesia menjalankan indutri asuransi syariah. Perihal itu, baru tahun 2001 MUI mengeluarkan fatwa, padahal perusahaan asuransi syariah lebih dahulu berdiri tahun 1994. Terbentuknya undang-undang asuransi syariah di Indonesia baru lahir tahun 2014. Respon pemerintah Indonesia yang masih terlihat kurang peduli dibandingkan dengan malaysia yang sudah tertata secara sistematis.

Keterangan diatas dapat disimpulkan bahwa kegaiatan asuransi syariah di Indonesia dan Malaysia tampak setelah adanya modernisasi oleh para kaum Penjajah. Sistem asuransi sama-sama dikenal resmi dengan bentuk sebuah perusahaan setelah adanya sistem asuransi yang dikenalkan oleh kaum Barat. Karena kedua negara memiliki karakter masyarakat Islam yang kuat, masyarakat mulai mencari jalan lain agar sistem dari barat berformulasi sesuai dengan ajaran Islam. Terbentuknya Undang-undang dari kedua negara tersebut sesuai dengan teori yang dikembangkanaliran mazhab sejarah, bahwa hukum terbentuk dari karakter bangsa. Bedanya bahwa di Negara Malaysia secara konstitusi merupakan negara Islam, sehingga hukum yang berasal dari karakter bangsa tidak semurni pada pemikiran teori tersebut. Padahal nyatanya peran andil pemerintah juga melihat kebutuhan masyarakat tersebut.

Kedua negara berpandangan sama bahwa asuransi syariah berkiblat pada sejarah suku arab mengenai konsep aqilah yang juga dipraktekkan pada zaman rasulullah saw, riwayat hadisnya sebagai berikut (Al-Bukhari 1998):

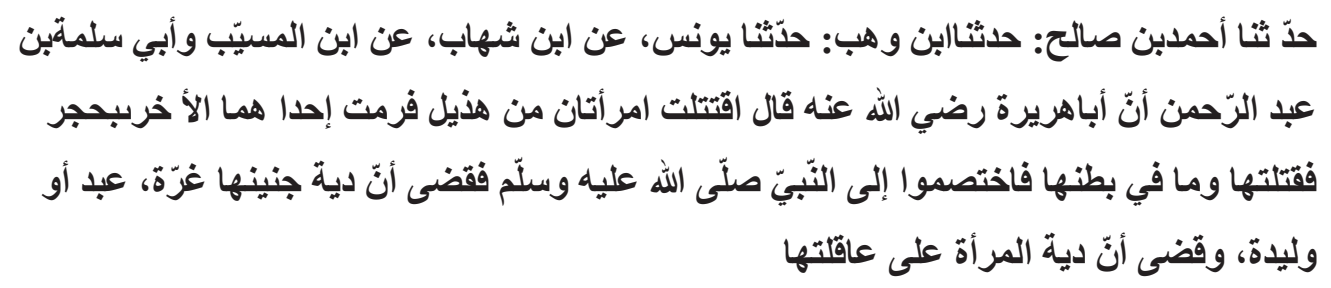

Selain hadis tersebut Islam juga mengajarkan untuk hidup saling tolong menolong, yang disampaikan dalam Alquran:

al-ạ̣kān Vol. 5, Nomor 1, 2020 


$$
\text { ... وتعاونوا على البرّوالتقوى ولاتعونواعلى الاثم والعدوان واتقّوا الله انّالله شديدالعقاب }
$$

Perkembangan asuransi syariah di Malaysia setiap tahun mengalami perkembangan, tahun 1993 lahir operator takaful kedua, yaitu Takaful Nasional. Pemerintah dan regulator terus mengembangkan industri takaful untuk mempercepat ekspansi bisnis. Dalam catatan perkembangannya BNM (Bank Negara Malaysia) selaku pegawas dan regulator industri Takaful mencatat pertumbuhan dari tahun ke tahun. Takaful di Malaysia dibagi menjadi dua bisnis, Takaful Keluarga (Asuransi Jiwa) dan Takaful Umum (Asuransi Umum). Perkembangan dari tahun 2013-2018 Industri Takaful Malaysia secara konsisten mengalami pertumbuhan yang kuat. Tahun 2013 terdapat 12 perusahaan takaful dan 4 retakaful. Tahun 2014-2017 menjadi 11 industri takaful dan 4 retakaful. Dalam rangka upaya pengembangan industri keuangan Islam termasuk takaful, pemerintah Malaysia menerbitkan Undang-undang yang mengatur secara keseluruhan lembaga keuangan Islam. Pada undang-undang IFSA 2013 perusahaan takaful harus dipisahkan antara Takaful Keluarga dan Takaful Umum. Semua terealisasi pada tahun 2018, dengan jumlah 11 industri takaful Keluarga, 4 Takaful Umum, dan 4 retakaful. Malaysia mensyaratkan bagi perusahaan industri takaful untuk langsung full fledge. Perubahan ini membuktikan konsistensi pemrintah Malaysia untuk terus melakukan kemajuan keuangan Islam.

Indonesia yang cukup jauh dan terlambat dalam industri keuangan asuransi syariah cukup mengalami pertumbuhan yang baik. Semenjak pendirian industri asuransi syariah tahun 1994, dengan menekankan asuransi syariah memiliki sistem kemanusiaan, meringankan, adil dan menentramkan berusaha untuk menarik keinginan masyarakat sebanyak mungkin. Sama dengan Malaysia asuransi syariah di Indonesia terbagi menjadi dua produk, yaitu asuransi jiwa syariah dan asuransi umum syariah. Namun di Indonesia terdapat dua bentuk perusahaan, Induk Usaha dan Unit Usaha.

Rupanya bisnis asuransi syariah di Indonesia dinilai sangat menjanjikan dan akan terus berkembang, karena Islam menjadi mayoritas di Indonesia. Jumlah Penduduk Islam yang banyak juga menarik para pengusaha luar negeri ataupun dalam negeri untuk mendirikan indutri asuransi syariah di Indonesia. Terlihat dari tahun 2013 dengan total 54 industri asuransi syariah, yang terdiri dari 5 perusahaan asuransi syariah dan 49 unit usaha suransi syariah. Sampai tahun 2018 telah tumbuh mencapai total 62 insutri asuransi syariah, yang terdiri dari 13 perusahaan asuransi syariah termasuk 1 reasuransi syariah dan 49 unit usaha asuransi syariah termasuk 2 reasuransi syariah. Pemerintah Indonesia terus menghimbau kepada industri asuransi syariah agar uint usaha segera spin off sampai batas waktu paling lama tahun 2024.

Dilihat dari segi aset yang dimiliki Malaysia dan Indonesia mengalami pertumbuhan aset yang konsisten sejak tahun 2013-2018. Nilai aset yang dimiliki Malaysia tahun 2013 
20,934.2 juta RM hingga 2018 aset menjadi 31,373.8 juta RM. Sedangkan Indonesia, memiliki total aset tahun 2013 dengan nilai Rp. 16.661.000.000,- hingga tahun 2018 total aset menjadi Rp. 41.959.000.000,-. Perbedaan nilai aset yang dimiliki Malaysia dan Indonesia menunjukkan bahwa Malaysia lebih banyak nilainya. Hal ini disebabkan karena industri takaful di Malaysia jauh lebih dahulu berdiri sehingga aset yang dimiliki juga lebih banyak. Perestasi perusahaan yang diminati oleh banyak konsumen juga menjadi daya tarik bagi investor. Sebuah tugas bagi Indonesia untuk terus menumbuhkan aset yang miliki dengan cara menarik konsumen maupun investor.

Industri asuransi syariah di Indonesia maupun Malaysia sama-sama memiliki keinginan yang kuat untuk terus memperbaiki kondisi keadaan dengan berbagai kebijakan. Indonesia memiliki perusahaan asuransi syariah yang cukup banyak dibandingkan Malaysia, namun aset yang dimiliki jauh lebih banyak Malaysia daripada Indonesia. Hal ini terjadi karena Malaysia lebih bergerak terlebih dahulu dalam praktikknya. Dampaknya juga inklusi dan literasi keuangan Islam Malaysia lebih tinggi daripada di Indonesia. Tampaknya hal tersebut membuat Indonesia terus mengikuti kebijakan-kebijakan pola industri asuransi syariah Malaysia. Seperti halnya kebijakan spin off yang harus dilakukan unit usha asuransi syariah di Indonesia, karena Malaysia sudah sejak awal menerapkan pola full fledge.

Pengembangan asuransi syariah secara komprehensif dilaksanakan dengan baik dan mempunyai arah tujuan yang jelas baik di Indonesia dan Malaysia. Nyatanya pengembangan asuransi syariah di kedua negara tersebut memiliki muatan-muatan perbedaan. Masingmasing negara memiliki kergaman sosial, budaya, aspirasi poltik dan kemampuan ekonomi. Perbedaan tersebut disebabkan oleh berbgaia faktor yang melatar belakangi. Dari faktor-faktor tersebut dilanjutkan dengan cara mengatasi dan menyelesaikan agar dapat melakukan pembenahan pada masing-masing negara. Bahwasanya manfaat perbedaan yang ada dapat dijadikan acuan satu sama lain agar pencapaian ekonomi keuangan asuransi syariah mendunia.

Perbedaan pengembangan asuransi syariah di Indonesia dan Malaysia disebabkan oleh beberapa faktor. Pertama, faktor kebiasaan masyarakat adat, bahwa sejak sebelum masa penjajahan di Malaysia lebih dahulu mengenal praktik menyerupai asuransi, sedangkan di Indonesia hanya mengenal asas gotong royong. Kedua, faktor pengenalan asuransi dari penjajah yang berbeda, Malaysia oleh Inggris dan Indonesia oleh Belanda. Seperti diketahui, bahwa asuransi dikenal pertama kali di Inggris. Meskipun praktik asuransi telah menyebar ke berbagai penjuru dunia. Pengelolaan oleh Inggris lebih baik dibandingkan pengelolaan yang lain. Sehingga, negara jajahan Inggris yaitu Malaysia dirasa memiliki pola pemikiran yang diwariskan oleh kolonial, oleh sebab itu praktik asuransi di Malaysia jauh lebih berkembang. 
Faktor ketiga, disebabkan oleh sistem pemerintahan dari kedua negara tersebut. Bahwa Malaysia jelas-jelas lebih mengungkapkan sistem pemerintahan Islam. Sedangkan Indonesia tidak menganut sistem pemerintahan islam, namun masyarakatnya yang meyoritas pemeluk agama Islam. Hal tersebut menjadi tingkat kesulitan pengenai politik ekonomi Islam. Faktor tingkat kesadaran masyarakat masing-masing negara yang berbeda. Minat dan kesadaran masyarakat Malaysia jauh lebih maju dan pesat karena modernisasi dan keterbukaan fikiran lebih dominan. Di Indonesia kebanyakan hanya masyarakat modernisasi yang sadar akan pentingnya berasuransi, sedangkan masyarakat tradisional masih memiliki pola pikir belum terbuka.

Faktor Eknomi Islam Malaysia jauh lebih memiliki eksistensi secara global dibandingkan Indonesia yang masih mengejar keterlambatan. Faktor waktu pembentukan asuransi syariah dari masing-masing negara berbeda, karena Malaysia jauh lebih dahulu dibandingkan Indonesia. Faktor kesadaran para pakar hukum Islam yang lebih dahulu melihat keadaan perekonomian global serta kebutuhan masyarakatmya, sehingga fatwa yang dikeluarkan dari Malaysia lebih cepat. Sedangkan Indonesia fatwa mengenai pedoman asuransi syariah sendiri terbelkang setelah berdirinya perusahaan takaful. Sebagai catatan bahwa Indonesia bercermin dan mengikuti pola perkembangan takaful Malaysia. Sehingga wajar apabila pengembangan asuransi syariah di Indonesia lebih lambat dibandingkan Malaysia.

Faktor yang mendasari semua yang di paparkan diatas adalah terbentuknya undangundang asuransi syariah di Indonesia dan Malaysia. Malaysia lebih mengutamakan aturan yang lebih dahulu terbentuk sedangkan Indonesia perusahaan berjalan sendiri tanpa adanya suatu aturan yang mengatur. Padahal indutri membutuhkan suatu pengendali untuk menertibkan dan mengorganisir dalam pengelolaannya. Pengendali tersebut yaitu undangundang sebagai hukum yang mengkontrol jalannya asuransi syariah.

Adanya suatu peraturan hukum yang mengatur lebih tersistematis mengenai hubungan antara industri dan konsumen serta industrisebagai penyumbang pembangunan ekonomi ke negara. Peraturan hukum juga untuk menjamin konsumen dalam kegiatan asuransi syariah yang diharapkan oleh masyarakat. Berbagai tujuan dari undang-undang asuransi syariah digunakan sebagai langkah pasti dalam tuntutan perubahan sosial. Hubungan peraturan perundang-undangan sebagai hukum pada masyarakat tentu akan meningkatkan daya tarik masyarakat dalam suatu kepercayaan atas kegiatan asuransi syariah.

Hukum sebgaia rekayasa sosial menjadikan hukum sarana implementasi keputusan politik dan kehilangan kehidupan tradisional. Ungkapan tersebut menurut penyusun sudah tidak relevan dengan perkembangan kehidupan modern di dunia ini. Sebagai rekayasa sosial diharapkan mampu melakukan perubahan yang lebih baik dan memiliki inegritas yang tinggi. 
Pelestarian nilai-nilai tradisional dirasa memang penting untuk menyelaraskan perubahan yang akan datang. Namun tidak terus menerus terbelenggu dengan sosial tradisional. Sebagai masyarakat yang terus menerus mengalami perubahan sosial diperlukan hukum untuk terus mengikuti perkembangan tersebut. Aturan undang-undang asuransi syariah sangat penting keberadaanya dalam pengembangan asuransi syariah.

hukum tetap selamnya berasal dari rakyat yang mengalami perubhan sosial sehingga aturan hukum ada dan terbentuk. Bentuk hukum tersebut dijalankan dan diaplikasikan untuk melakukan perubhan yang lebih maju terhadap masyarakat. Sehingga peran pemerintah sebagai regulator dan masyarakat sebagai pelaksana dari regulasi sekaligus masyarakat juga sebagai pembentuk dengan penyampaian aspirasi terhadap pemerintah. Sehingga hukum asuransi syariah sebagai alat kontrol sosial diartikan bukan sebagai kepentingan politik dan meninggalkan karakter masyarakat dalam pembentukannya. Justru peran masyarakat sebagai karakter yang kuat menjadikan suatu unsur untuk pembentukan hukum yang dicitacitakan dan sebagai perubahan sosial pada masyarakat agar lebih maju dan berkembang.

\section{Penutup}

Berdasarkan uraian yang telah dipaparkan dapat ditarik inti dari penelitian ini:

1. Undang-undang asuransi syariah di Indonesia dan Malaysia terbentuk berdasarkan jiwa bangsa. Kedua negara memiliki karakter masyarakat muslim yang memiliki peran terhadap pembentukan undang-undang asuransi syariah. Awal munculnya asuransi syariah di kedua negara tersebut berasal dari ideologi pragmatis yang dibawa oleh para penjajah Inggris bagi Malaysia dan Belanda bagi Indonesia. Peraturan asuransi syariah terbentuk menjadi sebuah undang-undang yang berawal dari adat kebiasaan masyarakat di masing-masing negara. Bahwa di Malaysia praktik asuransi telah dikenal semenjak masa pra-kolonial yang merupakan kebiasaan adat melayu dan tercantum pada undang-undang laut malaka. Sedangkan di Indonesia praktik asuransi kurang begitu nyata keberadaannya, hanya saja masyarakat adat yang menerapkan sistem gotong royong apabila terjadi musibah pada sesama anggota masyarakatnya. Dari perbedaan latar belakang kebiasaan masyarakat adat tersebut menimbulkan kesamaan pada kegelisahan akibat praktik asuransi yang ditanam oleh para penjajah karena mengandung unsur-unsur larangan dalam Islam. Sehingga menggerakkan para pakar dalam berijtihad, untuk tetap menerapkan sistem asuransi namun dengan prinsipprinsip Islam. Berangkat dari pemaparan tersebut yang dapat dikatakan dari sebuah jiwa bangsa, agar kebiasaan dapat berlaku secara menyeluruh maka lahirlah Undangundang asuransi syariah sebagai wujud peran negara untuk memberikan kepastian hukum secara sah. Masing-masing undang-undang pasti akan mengalami evolusi karena berangkat dari suatu aturan sebagai status di masyarakat menjadi kontrak. Kontrak akan

al-ạ̣kām Vol. 5, Nomor 1, 2020 
menunjukkan waktu habis berlaku yang disebabkan perubahan sosial masyarakat maka berubahlah aturan hukum tersebut.

2. Industri asuransi syariah yang terbentuk pada masing-masing negara Indonesia dan Malaysia ada perbedaan waktu. Malaysia tahun mulai tahun 1981 telah merencanakan adanya pembentukan takaful, dan terealisasi pada tahun 1984 dan diresmikan tahun 1985, yaitu PT. Syarikat Takaful Berhad. Sedangkan di Indonesia, berdirinya industry asuransi syariah terjadi pada tahun 1994 dengan berilmu pada Malaysia dan berdirilah PT. Syarikat Takaful Indonesia. Perbedaan jarak selama 10 tahun mengakibatkan pada perkembangan asuransi syariah di masing-masing negara. Sama-sama memiliki konsistensi dalam pengembangannya terdapat perbedaan aste yang dimiliki. Secara keseluruhan aset Malaysia jauh lebih banyak dan tingkat penggunaan jasa asuransi syariah menarik minat konsumen. Sedangkan di Indonesia aset lebih kecil daripada Malaysia padahal apabila di perbandingkan jumlah penduduk muslim di Indonesia lebih banyak. Selain itu, indutri asuransi syariah di Indonesia jauh lebih banyak daripada Malaysia. Seharusnya pasar di Indonesia jauh lebih tinggi daripada Malaysia. Hal tersebut menjadikan tugas serius bagi pemerintah maun marketing industri asuransi syariah untuk terus menggalakkan pemahaman masyarakat Indonesia pada pentingnya asuransi dan memberikan pengarahan mengenai kelebihan menggunakan jasa asuransi syariah. Bahwa asuransi syariah hadir sebagai alternatif bagi adanya sistem asuransi konvensional. Selain pemahaman masyarakat peraturan yang dibuat harus ditegakkan dalam pengelolaan indsutri perusahaan. Agar industry asuransi syariah terpercaya dan dapat mengemban amanah sesuai koridor ketetapan hukum.

3. Perbedaan pengembangan asuransi syariah di Indonesia dan Malaysia diakibatkan dari pembentukan undang-undang yang terjadi pada masing-masing Negara. Melihat konsistensi Malaysia selang setahun sebelum berdirinya perusahaan operator takaful telah menerbitkan Takaful act 1984. Sedangkan Indonesia terbentuknya UU Asuransi Syariah tahun 2014, padahal pengoperasian industry asuransi syariah sudah sejak tahun 1994. Dengan demikian UU Asuransi Syariah sebagai Hukum memiliki peran penring terhadap pola tingkah laku masyarakat. Perubahan sosial masyarakat dengan bentuk pemahaman terhadap praktik asuransi syariah terdorong karena adanya Undangundang sebagai alat kontrol sosial. Dampak yang ditimbulkan mengakibatkan pola perkembangan insdutri asuransi syariah akan pemahaman kepentingan pemakaian jasa tersebut menjadi kurang dilirk oleh masyarakat. Akibatnya di Indonesia yang merupakan populasi muslim terbanyak di dunia mengalami terbelakang pada bidang keuangan asuransi syariah. Sedangakan Malaysia, sudah lebih dahulu mendunia dan memiliki integritas tinggi pada bidang keuangan takaful. 


\section{Daftar Pustaka}

Al-Bukhari, Al-Imam Abi Abdullah Muhammad Ibn Isma'il. 1998. Saḥiḥ Al Bukhari. Amman: Bayt al-Afkar al-Dawiyyah.

Ali, A. Mukti. 1995. "Agama Dan Perkembangan Ekonomi Di Indonesia Dalam." In Kontekstualisasi Ajaran Islam: 70 Tahun Prof. Dr. H. Munawir Sadzali, MA. Jakarta: Paramadina.

Bank Muamalat. 2016. "Profil Bank Muamalat." Bank Muamalat. 2016. https://www. bankmuamalat.co.id/profil-bank-muamalat.

Billah, Mohd Ma'sum. 2010. Kontekstualisasi Takaful Dalam Asuransi Modern: Tinjauan Hukum Dan Praktik. Edited by S Suparto. Selangor: Sweet \& Maxwell Asia.

Burhanudin, B. 2010. Aspek Hukum Lembaga Keuangan Syariah. Yogyakarta: Graha Ilmu.

Burhanudin, Jajat. 1998. "Arkeologi Dan Kajian Islam Di Indonesia (Pengantar Editor)." In Menemukan Peradaban: Jejak Arkeologis Dan Historis Islam Di Indonesia, edited by Hasan Muaraif Ambary. Jakarta: Logos Wacana IImu.

Dewan Perwakilan Rakyat Republik Indonesia. 2010. Keputusan Dewan Perwakilan Rakyat RI No. 41 A/DPR RI/I/2009-2010 Tentang Persetujuan Penetapan Program Legislasi Nasional Tahun 2010-2014. Indonesia.

Dubai the Capital of Islamic Economy. 2016. "An Inclusive Ethical Econom: State of The Global Islamic Economy Report 2018/19." New York.

Fauzi, Puteri Nur Farah, and Mohd Naadia. 2016. "Takaful: A Review on Performance, Issues, and Challenges in Malaysia." Journal of Scientific Research and Development 3 (4).

Hadijah, Siti. 2018. "Sejarah Asuransi, Seperti Apa Perkembangannya Sampai Sekarang." Cermati Dot Com. 2018. https://www.cermati.com/artikel/sejarah-asuransi-sepertiapa-perkembangannya-sampai-sekarang.

Haron, Sudin. 2005. Sistem Kewangan Dan Perbankan Islam. Kuala Lumpur: Kuala Lumpur Business School SDN BHD.

International Business Public. 2015. Malaysia Banking and Financial Handbook Volume 1: Strategic Information and Regulations. Washington DC: Int'I Business Publications.

Kontan. 2018. "Revisi UU Asuransi Tak Kunjung Usai.” Kontan. 2018. https://keuangan. kontan.co.id/news/revisi-uu-asuransi-tak-kunjung-usai.

Mahmood, Nik Ramlah Binti Nik. 1988. "Insurance Law in Malaysia." University of London.

Milne, RS, and K Diane. n.d. Mauzy Politics and Government in Malaysia. Singapore: Federal Publications.

Nasution, Khoiruddin. 2002. Status Wanita Di Asia Tenggara: Studi Terhadap PerundangUndangan Perkawinan Muslim Kontemporer Di Indonesia Dan Malaysia. Jakarta: INIS.

---. 2009. Hukum Perdata (Keluarga) Islam Indonesia Dan Perbandingan Hukum Perkawinan Di Dunia Muslim. Yogyakarta: Academia \& Tazzafa.

Noordin, Kamaruzuman, and Djafri Fares. 2016. "Issues and Challenges in Introducing Islamic Insurance (Takaful) into the Algerian Financial Market: Lessons from Malaysia." In Contemporary Issues and Develompent in the Global Halal Industry: Selected Papers 
from the Internasional Halal Conference 2014. New York: Springer.

NU Online. 2018. "Sejarah Pergulatan Hukum Lembaga Asuransi Syariah." NU ONline. 2018. https://islam.nu.or.id/post/read/ 105826/sejarah-pergulatan-hukum-lembagaasuransi-syariah.

Nurwidiatmo. 2008. "Tim Analisis Dan Evaluasi Hukum Tentang Perasuransian (Asuransi Syariah) UU No. 2 Tahun 1992." Jakarta.

Prodjodikoro, Wirjono. 1986. Hukum Asuransi Di Indonesia. Bogor: Intermasa.

Rahardjo, Dawam. 1999. Islam Dan Transformasi Sosio-Ekonomi. Jakarta: Lembaga Studi Agama dan Filsafat.

Rahim, Rahimin Affandi Abdul, and Mohd Anuar Ramli. 2007. "Mazhab Syafi'i Dalam Pengajian Syariah Di Malaysia: Satu Analisis." Jurnal Fiqh, no. 4.

Rivai, Veithzal dkk. 2011. Islamic Transaction Law in Bussiness Dari Teori Ke Praktik. Jakarta: Bumi Aksara.

Rusman, Ignatius. 2016. Sejarah Dan Perkembangan Asuransi. Aca Asuransi.

Suhendi, Hendi. 2013. Figh Muamalah. Jakarta: Rajawali Pers.

Thajudeen, Kulsanofer Syed. 2014. "IFSA 2013: Rationale, Salient Features and Possible Issues." In INCEIF The Global University in Islamic Finance. Kuala Lumpur: Bank Negara Malaysia.

Thanasegaran, Haemala. 2018. "Growth of Islamic Insurance (Takaful) in Malaysia: A Model for The Region?" Singapore Journal of Legal Studies.

Umam, Chairul. 2014. "Melihat Hal-Hal Krusial Dalam Wajah Baru Undang-Undang Perasuransian." Jurnal Rechtsvinding: Media Pembinaan Hukum Nasional.

Viva. 2018. "Penyebab Minimnya Minat Masyarakat Terhadap Asuransi Syariah." Viva. 2018. https://www.viva.co.id/berita/bisnis/1078610-penyebab-minimnya-minatmasyarakat-terhadap-asuransi-syariah.

Yasin, Nur. 2009. Hukum Ekonomi Islam: Geliat Perbankan Syariah Di Indonesia. Malang: UIN-Malang Press.

Yeong, Eva. 2018. "Kesepakatan M\&A Diharapkan Dalam Takaful Industri." Malaysian Takaful. 2018. http://www.malaysiantakaful.com.my/Media-Room/MTA-in-thenews/News/M-A-deals-expected-in-takaful-industry.aspx. 